MISCELÁNEA LITERARIA: “LA NIÑA",

“MUÑECA ROTA", “LA CASA DE LAS PAREDES AZULES” Y

"FRONTERA INVISIBLE"1

\author{
Saliha Arrais Maridi ${ }^{2}$
}

\title{
La niña
}

Vestida de blanco.

Y allá fuera se escuchan canciones.

Y no hablan de ella, ni de sus ojos negros,

Que ya no son negros, sino grises.

Y no hablan de su mirada,

Que ya no habla de cielos, ni de surcar países,

ni de viajes, ni de paisajes.

\footnotetext{
${ }^{1}$ Fecha de recepción: 11/11/2020.

Fecha de aceptación: 22/12/2020.

${ }^{2}$ Saliha Arrais Maridi, almeriense de origen marroquí-rifeña, es graduada en Filología Hispánica por la Universidad de Almería. Especializada en docencia, actualmente trabaja como educadora en mediación intercultural, mientras prepara las oposiciones para profesora de lengua y literatura y escribe un libro de cuentos bereberes que se sustentan en la tradición oral (sus protagonistas son mujeres rifeñas contadoras de cuentos), cuyo título será Cuentos de La-lla Mennana. Convencida del poder que tienen las palabras, a veces escribe para expresar sus pensamientos-sentimientos-emociones, su tema favorito es la denuncia del arrebato de una infancia digna, el derecho a la vida, la denuncia de fronteras (en defensa de los puentes entre culturas), y siempre empleando un discurso que aboga por la comunicación, la empatía y la riqueza que nos brinda la diversidad, asegura que convivir entre culturas nos permite aprender y crecer desde el punto de vista humano. Además de cultivar el arte de la literatura, profundiza en el de la fotografía, su objetivo es, palabras textuales: "desnudar mi alma en una sola fotografía”; $\square$ salihaarrais@ gmail.com.
} 
Su vestido blanco, con perlas azules,

y un velo que cubre su cara...

No vaya a ser que se den cuenta que todavía es una niña con mofletes,

Que sueña con jugar con su muñeca sentadas las dos en un taburete.

Le dicen La niña

porque ni tiene pecho

ni lleva aretes,

Solo soñaba con saltar en charcos

y mirar paisajes,

y correr descalza por los montes;

allá donde los sueños no sean negros, ni rojos, ni grises.

Donde el miedo no entre por la puerta

Y le robe sus juguetes.

Solo era una niña

Con unos aretes.

Tenía una muñeca

Y ahora está rota, tirada con un taburete.

\section{Muñeca rota}

Había una vez, en un pueblo del que sí quiero acordarme, una muñeca sin una niña que pudiese jugar con ella... 
Soñé que le regalaba una muñeca a una niña. La pequeña, alegre y feliz, jugaba con su pequeña muñeca. Pero, de repente, la muñeca empezó a descomponerse. Entonces, la niña, desesperada cogía cada trozo y lo intentaba encajar: los brazos, las manos, el pelo... Pero cada vez que lo hacía, la muñeca se volvía a descomponer, y la niña empezaba a desesperar. Cuando la niña, ya cansada de arreglar a su muñeca, la vi desde lejos convertirse en un fantasma. No entendí el porqué de tal decisión. No entendí tal causa. La niña empezaba a caminar por lugares oscuros, tristes. Estaba atormentada. Sus ganas de intentar recuperar a su muñeca, no cesaron. Y, aun siendo ya fantasma, intentaba componer las partes de su muñeca, hasta que un día, de casualidad, yo iba caminando por un callejón, me encontré con la niña, con rabia, me miró y me dijo:

- Es tu culpa, solo tu culpa que yo ahora sea un fantasma. Me regalaste una muñeca rota, y por eso yo nunca pude componerla.

Recuerdo el color del miedo que habitaba sus ojos negros, ya grises. Él se viste de negro, de rojo, y cada vez que la visitaba, ella era un poco más fantasma. No tenía voz, apenas unos gemidos de dolor en su garganta se asomaban a una ventana...

- Me perteneces, eres mi princesa prisionera -le decía-, en susurros cuando estaba ella atada a una cama.

Dejó de vivir. Murió en vida.

A veces, la niña, ya mujer, se cerraba en un minúsculo armario, e intentaba dibujar a aquella muñeca; esa muñeca a la que nunca volverá a tener. Esa muñeca que destruyeron para ella.

Esa muñeca con la que nunca pudo jugar, porque alguien se la arrebató, y con esa muñeca se fueron sus ganas de soñar con el cielo azul, con mojar sus pies en un charco, o saborear unas golosinas de manzana.

Se quedarán las ganas, solo eso. 
"Me quedaré con las ganas de un recuerdo que me pudiese alentar. Y, ahora, solo puedo decir que aquella muñeca y yo tenemos más en común de lo que yo pensaba. Tan indefensas, tan rotas, y tan difícil de construirnos. Nos mataron. Nos quitaron la vida, con su sonrisa, y no supimos ni perder la inocencia en condiciones".

Guarda la niña una muñeca en un baúl ya viejo, más viejo que su alma, con la esperanza de poder un día jugar con ella.

La niña, ya mujer, cada vez que duerme sueña con esa niña. La niña tan solo tenía doce años. Recorría un campo verde, gritando al aire libre, descalza, y con un cielo con el que podía soñar.

\section{La casa de las paredes azules}

La casa de las paredes azules, la llamaba yo, la pensaba yo.

Un patio enorme, con un cielo azul celeste, al descubierto.

En ella las mañanas eran mañanitas mañaneras, de carcajadas y risas.

En la mesa un platito con zit-baldiya, pan tostado y café de mi abuela; para nosotros con mucha leche, y para ella algo cargado. Y si nos quejábamos nos decía "vosotros sois niños". Y eran así todas las mañanas: mañanitas mañaneras, de risas, de carcajadas y de alegría. Todos reunidos por una mesa a compartir la alegría, el pueblo sonreía, 
y si le gritábamos nos respondía: "tranquilidad, este es un pueblo de risas y alegría".

Mi abuela contaba anécdotas,

contaba cuentos, chistes y a veces nos cantaba.

Nosotros, sorprendidos, nos alegrábamos de tenerla a ella.

Un día pasó algo, y la casa se quedó vacía.

Pasaron muchos años y yo a esa mujer no veía.

Se cerraron las puertas y ventanas, y la casa se quedó vacía.

Recorrí todos los rincones de ese pueblo, preguntando por ella.

Me acerqué a un niño, y le pregunté “¿has visto a la señora alegría”?

Y el niño, triste, me respondió: "se fue en mayo, un día de primavera"

Y desde ese día sigo buscándola a ella,

En cada rincón,

en cada primavera.

\section{Frontera invisible}

Tus manos alzadas,

tus dedos en movimiento

y esas líneas que hay en ellas,

que ponen símbolo a esta frontera

que hay entre tus dedos y los míos.

Tus manos. Las mías. 
Y hay quien llama huella

a la frontera que hay entre tus ojos y los míos.

Y nos miramos, sin vernos.

Y nos oímos, sin escucharnos.

Apenas un ruido,

Apenas un chillido,

que despierta el sueño de esta frontera que duerme entre nuestras manos. 